Article

\title{
The Effects of Creating Shared Value on the Hotel Performance
}

\author{
Manuel Ángel Fernández-Gámez ${ }^{1}$, A. Manuel Gutiérrez-Ruiz ${ }^{2, *}$, Rafael Becerra-Vicario ${ }^{1}$ and \\ Daniel Ruiz-Palomo ${ }^{1}$
}

1 Department of Finance and Accounting, Campus El Ejido s/n, University of Malaga, 29071 Malaga, Spain; mangel@uma.es (M.Á.F.-G.); rbecerra@uma.es (R.B.-V.); drp@uma.es (D.R.-P.)

2 PhD Program of Mechanical Engineering and Energy Efficiency, Campus de Teatinos s/n, University of Malaga, 29071 Malaga, Spain

* Correspondence: amgruiz@uma.es

Received: 27 February 2019; Accepted: 19 March 2019; Published: 25 March 2019

check for updates

\begin{abstract}
The current literature on sustainable practices shows that social missions and economic achievement can be compatible. However, very few studies have offered a quantitative perspective on this relationship. This study presents the first empirical evidence of the effects of the creating shared value (CSV) principle on the performance of companies. Using a sample of Spanish hotels, the results suggest that companies that apply CSV achieve higher financial performance. These findings represent a substantial contribution to the literature and shed light on how to efficiently implement CSV practices to simultaneously achieve economic and social benefits.
\end{abstract}

Keywords: creating shared value; sustainable practices; partial least squares (PLS); hotel performance

\section{Introduction}

The creating shared value (CSV) principle has generated great interest among companies and researchers because integrates a set of policies and operational practices that help to improve the sustainable development of society [1-4]. CSV proposes innovation in three dimensions that complement each other building to a virtuous circle: reconceiving products and markets, redefining productivity in the value chain, and enabling the development of a local cluster [1,5].

Many theoretical studies have addressed the conceptual framework of CSV and its effects. These studies have also offered several examples of shared value strategies in different countries and business sectors, highlighting the CSV practices of large multinational corporations [1,6,7]. However, very few studies have provided empirical evidence from a quantitative perspective. Most of these studies have been based on case research that illustrates CSV but lack sufficient empirical data to support the arguments of the authors [3]. There are also very few studies on CSV that have addressed the tourism industry, and most of them have only investigated the association between CSV and the organizational behavior of specific tourism companies or the impact of responsible tourism [8-12]. Given the scarcity of empirical studies on CSV, new research is needed in which claims regarding the benefits of CSV are supported by data [3].

Taking this situation into account and the scarcity of such studies on the tourism industry, in particular, the present study attempted to deepen the empirical understanding of how companies that make greater CSV efforts achieve higher financial performance. Data were obtained on a sample of hotels in Malaga province (Spain) that have a great social impact on their environment. These data were used to develop a comprehensive path model that integrates CSV constructs, financial performance indicators, and specific characteristics that affect hotel activity. This model was tested using partial least squares (PLS). We followed a two-step approach to build a second-order CSV, measured through 
three first-order reflective constructs (reconceiving products, redefining productivity in the value chain, and strengthening clusters). After that, we used a Measurement Invariance of Composites Model procedure (MICOM) to ensure that their scores do not differ across groups, and a set of techniques to test moderation effects (Multigroup analysis, Welch-Satterthwait, and parametric and permutation tests). A significant and positive association was found between the CSV efforts made by hotels and their financial performance. The proposed model has an exceptional capacity to predict the CSV strategy of hotels.

The rest of this article is structured as follows: We present a review of the CSV literature and the study hypotheses; we then describe the methodology and present the results of developed path model; and finally, we provide the main conclusions and managerial implications.

\section{Literature Review and Hypotheses}

Organizations have come to recognize the need to identify the expectations of a large group of stakeholders in order to define strategies that can fulfil these expectations. Such strategies should combine a respectful and proactive attitude towards stakeholders while providing success and value creation for the firms [13,14]. The CSV principle centers on identifying and expanding the connections between social and economic progress. It is characterized by procedures that improve the firms' competitiveness while promoting better social and economic conditions for the communities in which the firms operate [1,6,15-17]. Porter and Kramer [1] suggested that CSV not only presumes compliance with the law and ethical standards, and mitigates negative impacts caused by business, but also goes beyond these aspects; it represents a new way to understand how customers, productivity, and external influences affect company success. Thus, companies can move towards sustainable development and create value for the community rather than limiting their strategies to the reactive resolution of specific environmental issues [18-20]. However, research on social entrepreneurship shows that there are tensions inherent to the simultaneous creation of social benefits and economic value [21], but these tensions can be resolved and the fundamental socio-economic transformation sought by CSV can be achieved over time [22].

Currently, a shared value between society and companies is built by corporate social responsibility, which only operates at the level of damage control or public relations campaigning. Porter and Kramer [13] suggested that companies need to take a further step from corporate social responsibility to CSV. That is, CSV should guide company investment in communities [1] because this is the best way for companies to restore legitimacy, increase confidence, and improve their reputation $[23,24]$.

In practice, CSV involves three strategies that comprise a virtuous circle, such that an increase in the value of one of them will increase opportunities in the others. The three strategies are: reconceiving products, redefining productivity in the value chain, and strengthening clusters [1]. Reconceiving products involves creating innovative products that meet previously unmet needs in the market [25]. The need to reconceive products is related to many societal needs (e.g., health, better housing, improved nutrition, aid for the elderly, greater financial security, and less environmental damage). Entrepreneurs should innovate and reformulate their distribution methods or products in such a way that the needs of their customers are met [1]. There is a rapidly increasing demand for products and services that satisfy the needs of the community in developed economies. Therefore, companies should conduct continuous research into new social needs, thus allowing them to differentiate themselves from other companies and discover new opportunities [26].

Redefining productivity in the value chain means that companies have to first identify their positive and negative social impact and then re-imagine value chains and redefine productivity accordingly. The so-called value chain is a management tool to conduct an internal analysis of the company through the disaggregation of its main value-generating activities, such as human resources management, technology development, and procurement [27]. The value chain of an organization is influenced by several social aspects, such as the management of raw materials and water, safety and health at work, the working conditions of employees, and equal gender opportunities at the workplace. 
The opportunity for CSV lies in the associations between society and companies [1]. To introduce CSV in the value chain Porter and Kramer [1] proposed changes to the use of energy and logistics. These changes would involve new approaches to energy efficiency in order to save costs and respect the environment. Changes can also be made to logistics; for example, some companies are attempting to reduce shipping routes and improve vehicle routes [28]. In addition, supply can be improved via the suppliers. Companies can share technology with suppliers and offer them funding such that they can become more competitive and offer higher quality products. Porter and Kramer [1] also suggested interventions on employee productivity that could increase company profits. These interventions could include the implementation of policies that ensure a minimum living wage and job security, and that promote welfare, training, and developmental opportunities.

Finally, regarding strengthening clusters, Porter and Kramer [1] explained the benefits of geographical clustering of companies, specialized suppliers, institutions (e.g., universities or business schools), and business associations working in a given field. Strengthening clusters generate a new value that is rooted in the idea that the success of any company is affected by supporting businesses and by the infrastructure in the area. Clusters encourage competition and cooperation between companies and organizations and represent a robust form of organization that provides advantages in terms of efficiency, effectiveness, and flexibility. Given that deficiencies in structural conditions may entail internal costs to the organizations, it has been recommended that efficient clusters should be constructed in areas in which business operations are conducted [1]. The existence of clusters has a strong influence on innovation and productivity. Therefore, when a company attempts to strengthen clusters it is also developing a CSV strategy because the company is helping to reduce social, educational, and institutional problems in that area while receiving benefits derived from improved productivity and lower internal costs [26].

An active approach to CSV requires ideas and actions capable of embedding this principle within the corporate culture. This approach could be achieved by defining a clear social objective that can be reported or embedded in the strategic plans and budgets of organizations [6].

Many early theoretical studies have attempted to improve the CSV conceptual framework [3]. However, few studies have provided empirical evidence from a quantitative perspective, given that most of them have been based on small case research that illustrates CSV but lack sufficient empirical data to support the arguments of their authors. As pointed out by Reference [3] the majority of these studies were conducted by Porter and Kramer and other authors who belonged to FSG Consulting or Harvard University (e.g., References $[1,6,13,29])$. In addition, the data used in these studies were mainly obtained from internal documents provided by the corporation or from interviews with their managers. Only Sojamo and Larson [30] used additional sources from outside the companies. Two studies on CSV were based on reports provided by company executives [31,32], although the number of informants per organization was limited.

Very few publications have addressed CSV in the tourism industry (e.g., References [9-12,33]), and even fewer have investigated the association between CSV and corporate behavior and the effects of responsible tourism. Drozdz et al. [9] studied correlations between social value and economic benefit for restaurants. They found that Swedish restaurant companies genuinely work to create economic benefit and social value, but failed to find a clear pattern between these variables. Hsiao and Chuang [10] explored the preliminary framework of green practices to configure the value chain and proposed a conceptual model based on a CSV perspective in the case of hotels. Their results showed how hotels could implement green practices efficiently to simultaneously obtain economic benefits and environmental protection. In the case of tourism in a Swiss region, Grezes and Perruchoud [11] developed an online application enabling the analysis of business models, offering to a large number of stakeholders the possibility of participating in the search for shared value, from a local or industrial perspective. Camilleri [33] conducted qualitative research using in-depth semi-structured interviews with hotel managers and owners. Camilleri suggested that responsible tourism leads to better associations with social and regulatory stakeholders, effective human resources management, 
better market positioning, and greater operational efficiency. Finally, Lim [12] analyzed the association between CSV, organizational loyalty, and organizational identity in employees in a luxury hotel in Korea. A positive correlation was found between CSV and organizational loyalty. This association was partially moderated by organizational identity.

Overall, this literature review suggests that companies that implement CSV strategies achieve competitive advantages $[13,14]$. Furthermore, some studies have found a relevant association between CSV practices and operational efficiency in the tourism industry [6]. However, there are no empirical studies on the effects of CSV strategies on financial performance in the hotel industry or on whether there is a clear and direct association between CSV and financial performance. Therefore, we propose the following hypotheses:

Hypothesis 1 (H1). The CSV strategy has a positive effect on the financial performance of hotels.

Given that previous studies have shown that characteristics such as star rating, size, market segment, and belonging to a particular group have an effect on finance performance [34-38], the second hypothesis is as follows:

Hypothesis 2 (H2). The characteristics of the hotel have a moderating effect on the relationship between CSV and financial performance.

Hypothesis 2 can be divided into the following sub-hypotheses:

Hypothesis 2a. (H2a). Hotel star rating has a moderating effect on the relationship between CSV and financial performance.

Hypothesis $\mathbf{2 b}$. (H2b). Hotel size has a moderating effect on the relationship between CSV and financial performance.

Hypothesis 2c. (H2c). The market segment of the hotel has a moderating effect on the relationship between CSV and financial performance.

Hypothesis 2d. (H2d). Belonging to a group has a moderating effect on the relationship between CSV and financial performance.

\section{Method}

\subsection{Data Collection and Social Impact}

The target population was hotels in Malaga province (Spain). This hotel population was chosen because Malaga province receives more than 7,100,000 tourists per year and has one of the main hotel offers in Europe. There are 431 hotels in this province with 304,000 places and an average annual occupancy rate close to $70 \%$ [39].

The study hypotheses were tested using data obtained from a questionnaire sent to all the hotels that are members of AEHCOS (Costa del Sol Hotel Association), which is an association representing more than $85 \%$ of the hotels in this province. The questionnaire was completed by hotel managers between April 2017 and July 2017. Of the 370 questionnaires sent, 130 were completed. Sample size satisfies Cohen's criteria [40] for a 0.99 significance level and a power of 0.8 (with $\mathrm{R}^{2}=0.1$ ). Table 1 shows the composition of the final sample. Of the hotels in the sample, 31.54\% (41 hotels) operate in the City market segment and $68.46 \%$ (89 hotels) operate in the Sun and Beach market segment. In addition, $60.77 \%$ (79 hotels) did not belong to a group and $62.31 \%$ ( 81 hotels) had a medium star rating. This sample accurately represents the current profile of the hotels in Malaga province, as shown by 
data collected by Reference [39], which confirm that most of the hotels operate in the Sun \& Beach market segment, do not belong to a group, and have a medium star rating.

Table 1. Sample by market segment, star rating and belonging to a group.

\begin{tabular}{|c|c|c|c|c|c|c|}
\hline & \multicolumn{6}{|c|}{ Market Segment } \\
\hline & & \multicolumn{2}{|c|}{ City } & \multicolumn{2}{|c|}{ Sun and Beach } & \multirow[b]{2}{*}{ Total } \\
\hline & & High-Category & Medium-Category & High-Category & Medium-Category & \\
\hline \multirow{3}{*}{ Belonging to a group } & Yes & 4 & 5 & 31 & 11 & 51 \\
\hline & No & 3 & 29 & 11 & 36 & 79 \\
\hline & Total & 7 & 34 & 42 & 47 & 130 \\
\hline
\end{tabular}

High-category: establishments with a 4 or 5 star rating; Medium-category: establishments with a 1, 2, or 3 star rating.

The activity of the 130 sample hotels has a great social impact. The added value generated by their economic activity for society as a whole in 2017 was $€ 145,634,255$. Of this total, $€ 97,925,619(67.24 \%)$ were paid as wages, $€ 32,409,777(22.25 \%)$ were distributed to the owners of the hotels in the form of economic profits, $€ 6,653,874(4.57 \%)$ were paid as taxes, and $€ 8,644,985(5.94 \%)$ were paid to banks. In addition, the community receives specific social value generated through activities unrelated to the market, which include: the enhancement, improvement, and environmental sustainability of the environment; the professional training of the workers and job offer services (e.g., AEHCOS, Costa del Sol Hotel Association, has a free section with job offers from the hotels belonging to the association); and the contribution to the tourist destination's reputation. The hotels in the location obtained an average of 82 points out of 100 on TripAdvisor, Facebook, or Twitter from users from Spain, the United Kingdom, France and Germany [41].

\subsection{Measurement}

The content of the study questionnaire was based on the literature on CSV $[1,18]$. It comprises a set of 31 questions, arranged in four sections (identification of the establishment and company, reconceiving products, redefining productivity in the value chain, and strengthening clusters). The questions in Sections 2-4 were answered by respondents on a 5-point Likert scale (ranging from $1=$ none to $5=$ substantial) (Appendix A). Table 2 shows the constructs, dimensions, and indicators used in the questionnaire. In addition, the questionnaire was prepared using in-depth semi-structured interviews with hotel experts from Malaga province (Appendix B). These interviews were largely exploratory. Subsequently, a group of academics reviewed the questionnaire to identify questions that could have been biased. Based on this feedback, some were modified or eliminated from the initial questionnaire, and other items were added to the final questionnaire.

Table 2. Constructs, dimensions and indicators used in the questionnaire.

\begin{tabular}{|c|c|c|}
\hline Construct/Dimension & Code & Indicator \\
\hline \multicolumn{3}{|l|}{ Reconceiving products } \\
\hline Sports facilities & PDT1 & $\begin{array}{l}\text { Sports facilities offer. } \\
\text { Spa, sauna, or solarium }\end{array}$ \\
\hline Nature activities & PDT2 & $\begin{array}{l}\text { The hotel is located in or near nature } \\
\text { Offers medical and health services }\end{array}$ \\
\hline Health services & PDT3 & Offers different types of pillows \\
\hline Cultural and commercial facilities & PDT4 & $\begin{array}{c}\text { Offers healthier and more nutritive products } \\
\text { Use of restored historic or artistic buildings } \\
\text { Offers business centers } \\
\text { Offers rooms with natural light }\end{array}$ \\
\hline
\end{tabular}


Table 2. Cont.

\begin{tabular}{|c|c|c|}
\hline Construct/Dimension & Code & Indicator \\
\hline \multicolumn{3}{|l|}{ Redefining productivity } \\
\hline \multirow{5}{*}{ Energy efficiency } & \multirow{5}{*}{ PVC1 } & Recent renovation of air conditioning systems \\
\hline & & Use of solar panels \\
\hline & & Use of automatic on/off systems \\
\hline & & Other technology for energy efficiency \\
\hline & & Workers with disabilities Absenteeism at Work \\
\hline Work incentives & PVC2 & $\begin{array}{l}\text { Workers with permanent contract or near-permanent } \\
\text { contract }\end{array}$ \\
\hline \multirow{4}{*}{ Care of the environment } & \multirow{4}{*}{ PVC3 } & Use of systems to reduce water consumption \\
\hline & & Use of a recycling system \\
\hline & & $\begin{array}{l}\text { Implementation of other environmental improvement } \\
\text { techniques Landscape areas }\end{array}$ \\
\hline & & Technologies shared with suppliers \\
\hline \multirow{4}{*}{ Support policy for suppliers } & \multirow{3}{*}{ PVC4 } & Aid provided to suppliers \\
\hline & & Use of supplier credit \\
\hline & & Purchasing from local suppliers \\
\hline & \multirow{3}{*}{ PVC5 } & Training programs for workers \\
\hline \multirow{2}{*}{ Worker training and safety } & & Health programs for workers \\
\hline & & Work safety programs for worker \\
\hline \multicolumn{3}{|l|}{ Strengthening clusters } \\
\hline \multirow{2}{*}{$\begin{array}{l}\text { Members of professional } \\
\text { associations }\end{array}$} & CLU1 & Collaboration with business associations \\
\hline & CLU2 & Quality certificates granted to the establishment \\
\hline \multirow{2}{*}{$\begin{array}{c}\text { Collaboration with scientific and } \\
\text { educational centers }\end{array}$} & CLU3 & Use of services provided by universities \\
\hline & CLU4 & Use of services provided by vocational training schools \\
\hline
\end{tabular}

Financial information about the sample hotels was used to quantify the financial performance variables used in this study. This information was obtained from the annual accounts that companies provide to Spanish commercial registry offices. These registries are official bodies that publish the compulsory yearly accounting statements of Spanish companies. These annual accounts include the company's main financial data (balance sheet, losses and profits, and annual reports) and meet the accounting standards required by the European Union.

\subsection{Research Model}

A comprehensive path model was constructed to test the study hypotheses. This model includes associations between different constructs. CSV is a second-order formative construct measured through three first-order reflective constructs: Reconceiving products, redefining productivity in the value chain, and strengthening clusters. Financial performance was measured using two continuous indicators: Gross Operating Profit per room and Total Revenue per room. The model uses four control variables for possible moderating effects on the relationship between CSV and financial performance: size, segment market, star rating, and belonging to a group. The size was estimated using the number of rooms, such that hotels with more than the median number of rooms were assigned value 1 and 0 otherwise. Market segments were divided into Sun and Beach (value 1) and City (value 0). Hotels with four or five stars were assigned a value 1 and 0 otherwise. Finally, if a hotel belonged to a group it was assigned value 1. Figure 1 shows the research model, study hypotheses, and moderating effects.

According to the proposed research model, three reflective (mode A) composite constructs comprise the first-order constructs that define CSV as a formative composite construct. Thus, a two-step approach was chosen because when a model defines the first-order reflective constructs and a second-order formative construct, the two-step approach is more appropriate than the repeated indicators approach $[42,43]$. The two-step approach is also more appropriate if the main research focus is on higher-level estimates [44]. After measurement invariance was ensured using a 
MICOM procedure [45], potential moderating effects were tested using three multigroup procedures: permutation tests [46], MGA-PLS Welch-Satterthwait tests, and parametric tests [47,48].

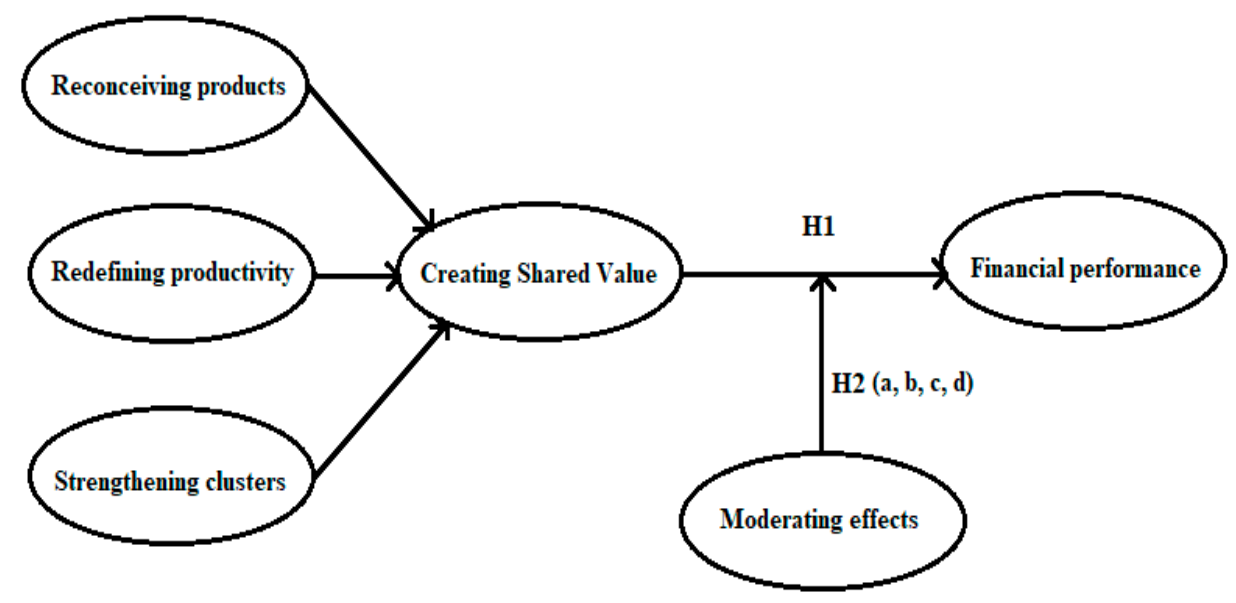

Figure 1. Research Model.

The research model was tested using partial least squares (PLS), otherwise known as variance-based structural equation modelling (SEM) [49]. PLS is particularly suitable for testing the proposed theoretical model because it can simultaneously estimate multiple relationships between latent constructs involving hierarchical variables and account for measurement error in the constructs [36]. PLS analyses are more flexible than covariance-based SEM to simultaneously model reflective and formative latent factors [44,50]. In addition, PLS-SEM can simultaneously assess the reliability and validity of the measures of theoretical constructs (outer or measurement model) and estimate the relationships between these constructs (inner model) [51,52]. PLS-SEM is primarily intended for causal-predictive analysis, where the problems explored are complex and prior theoretical knowledge is scarce [53]. Consequently, PLS-SEM is an appropriate technique to use in a theory development situation, such as that in the present study [52,54]. Traditional PLS is preferable because the study uses second-order models and does not have a sufficiently large data set (e.g., sample size of $n=300$ ) [55]. All statistical analyses were conducted using the Smart PLS 3.2.7 software package [56].

\section{Empirical Results}

\subsection{Statistical Tests for Bias}

The validity of the questionnaire was tested by analyzing two types of bias: non-response bias and common method bias. Firstly, non-response bias was tested by using late respondents as surrogates for non-respondents [57]. We compared the responses from hotels answering the first round $(75 \%$ of the sample) to those from hotels responding to the follow-up round ( $25 \%$ of the sample). No significant differences were found between the two groups using Student $t$ and chi-squared tests. Secondly, common method bias was minimized by the use of two data sources [58]. The partial correlation procedure suggested that the data did not suffer from the common method bias [59]. Thus, no evidence was found of non-response or common method bias.

\subsection{Outer Model Validation}

Each latent variable in the model was measured using multiple indicators and evaluated in terms of reliability, nomological validity, and composition weights [60]. Although reflective measures in lower-order constructs are assessed using measures such as Cronbach's alpha, composite reliability, and average variance extracted, it is inappropriate to assess formative constructs from an internal consistency perspective $[61,62]$, such as the higher-order construct CSV. Thus, the formative measurement model was assessed using the variance inflation factor (VIF) values for collinearity 
issues as well as the significance and relevance of indicators [43]. Significance was determined using a nonparametric (10,000 iterations) bootstrap procedure. Furthermore, predictive ability was assessed using the blindfolding procedure in Smart PLS to determine whether cross-validated commonalities and redundancies $\mathrm{Q}^{2}$ were more than 0 [63]. Table 3 shows the reliability and convergent validity of measures.

Table 3. Convergent validity and reliability of measures.

\begin{tabular}{|c|c|c|c|c|c|c|c|c|}
\hline LOC & Indicators & Loadings & $\mathrm{CVCQ}^{2}$ & $\mathrm{CVRQ}^{2}$ & $\alpha$ & $\rho_{\mathrm{A}}$ & $\mathrm{CR}$ & AVE \\
\hline \multirow{4}{*}{$\begin{array}{l}\text { Reconceiving } \\
\text { products }\end{array}$} & PDT1 & $0.79^{* *}$ & 0.44 & & \multirow[t]{4}{*}{0.79} & \multirow[t]{4}{*}{0.80} & \multirow[t]{4}{*}{0.86} & \multirow[t]{4}{*}{0.61} \\
\hline & PDT2 & $0.69^{* *}$ & 0.20 & & & & & \\
\hline & PDT3 & $0.82 * *$ & 0.36 & & & & & \\
\hline & PDT4 & $0.82 * *$ & 0.42 & & & & & \\
\hline \multirow{5}{*}{$\begin{array}{l}\text { Redefining } \\
\text { productivity }\end{array}$} & PVC1 & $0.73^{* *}$ & 0.34 & & \multirow[t]{5}{*}{0.81} & \multirow[t]{5}{*}{0.86} & \multirow[t]{5}{*}{0.86} & \multirow[t]{5}{*}{0.55} \\
\hline & PVC2 & $0.67^{* *}$ & 0.33 & & & & & \\
\hline & PVC3 & $0.84^{* *}$ & 0.39 & & & & & \\
\hline & PVC4 & $0.79 * *$ & 0.34 & & & & & \\
\hline & PVC5 & $0.68^{* *}$ & 0.30 & & & & & \\
\hline \multirow{4}{*}{$\begin{array}{l}\text { Strengthening } \\
\text { clusters }\end{array}$} & CLU1 & $0.63 *$ & 0.63 & & \multirow[t]{4}{*}{0.77} & \multirow[t]{4}{*}{0.89} & \multirow{4}{*}{0.84} & \multirow[t]{4}{*}{0.58} \\
\hline & CLU2 & $0.88 *$ & 0.88 & & & & & \\
\hline & CLU3 & $0.61^{* *}$ & 0.61 & & & & & \\
\hline & CLU4 & $0.89^{* *}$ & 0.89 & & & & & \\
\hline \multirow{2}{*}{$\begin{array}{c}\text { Financial } \\
\text { performance }\end{array}$} & GopPar & $0.86^{* *}$ & 0.41 & 0.03 & \multirow[t]{2}{*}{0.81} & \multirow[t]{2}{*}{1.08} & \multirow[t]{2}{*}{0.91} & \multirow[t]{2}{*}{0.83} \\
\hline & TrevPar & $0.96^{* *}$ & 0.32 & 0.13 & & & & \\
\hline HOC & Indicators & Weights & SD & $\mathrm{CVCQ}^{2}$ & VIF & & & \\
\hline \multirow[t]{3}{*}{ CSV } & Reconceiving products & $0.47^{* *}$ & 0.08 & 0.44 & 1.99 & & & \\
\hline & Redefining productivity & $0.43 * *$ & 0.05 & 0.52 & 2.43 & & & \\
\hline & Strengthening clusters & $0.25 *$ & 0.09 & 0.36 & 1.65 & & & \\
\hline
\end{tabular}

LOC: lower-order constructs; $\mathrm{CVCQ}^{2}$ : cross-validated communalities Stone-Geisser $\mathrm{Q}^{2}$ index; $\mathrm{CVRQ}^{2}$ : crossvalidated redundancies Stone-Geisser $\mathrm{Q}^{2}$ index; $\alpha$ : Cronbach's alpha; $\rho_{\mathrm{A}}$ : [64] Rho; CR: composite reliability; AVE: average variance extracted; HOC: higher-order construct; SD: standard deviation; VIF: variance inflation factor; ${ }^{*} p$ $<0.01 ;{ }^{* *} p<0.001$.

Most of the reflective indicators had loadings on their respective constructs of more than 0.71 [65]. Although five items had loadings that ranged from 0.61 to 0.69 , these loadings may be acceptable [66] if their rejection does not improve the model fit [43]. All the reliability indicators exceeded their shortcut values. Finally, in order to assess formative reliability, all the weights would have to be significant and VIF values would have to be less than three. If these conditions are met, then the composite construct would be well-formed [43].

As shown in Table 4, discriminant validity was assessed using cross-loadings (not reported), the Fornell-Larcker criterion, and the HTMT criterion in variance-based SEM [67].

Table 4. Discriminant validity.

\begin{tabular}{|c|c|c|c|c|c|}
\hline & & I & II & III & IV \\
\hline $\mathrm{I}$ & Financial performance & 0.911 & 0.185 & 0.326 & 0.373 \\
\hline II & Strengthening clusters & 0.180 & 0.763 & 0.796 & 0.632 \\
\hline III & $\begin{array}{l}\text { Redefining productivity in } \\
\text { the value chain }\end{array}$ & 0.307 & 0.620 & 0.742 & 0.882 \\
\hline IV & Reconceiving products & 0.342 & 0.497 & 0.701 & 0.782 \\
\hline
\end{tabular}

HTMT criterion results above the diagonal; Correlations below the diagonal; Squared-root of the AVE on the diagonal following the Fornell-Larcker criterion.

\subsection{Predictive Relevance}

As the first step in quality assessment, a blindfolding procedure (omission distance of 7) was used to assess the overall predictive relevance of the model $[47,68]$. Cross-validated redundancies and communalities had Stone-Geisser $\mathrm{Q}^{2}$ values of 0.102 and 0.442 , respectively. This finding supports 
the model's overall predictive relevance because the $Q^{2}$ values are more than 0 [47]. As a second step in quality assessment, goodness of fit (GoF) indicators for the structural model were assessed using the standardized root mean square residual (SRMR) and normed fit index (NFI). SRMR and NFI values of less than 0.08 and 0.90 , respectively, indicate a good fit [69,70]. Additionally, SRMR, geodesic discrepancy and unstandardized least squares discrepancy values were within the two-tailed $95 \%$ confidence interval [60]. The $\mathrm{R}^{2}$ and adjusted $\mathrm{R}^{2}$ values were both more than 0.10 .

These results suggest that the model is well formed, and thus that the theoretical model is correct $[60,71]$. Table 5 shows the inner model results and validation criteria.

Table 5. Inner model results and validation criteria.

\begin{tabular}{|c|c|c|c|c|c|c|}
\hline Second-Stage Inner Model & B & SD & LO95 & HI95 & $\mathrm{f}^{2}$ & VIF \\
\hline CSV $\rightarrow$ Financial performance & $0.338^{* *}$ & 0.072 & {$[0.202$} & $0.476]$ & 0.129 & 1.000 \\
\hline Overall validation criteria & Value & & & & & \\
\hline $\mathrm{Q}^{2}$ & 0.102 & & & & & \\
\hline SRMR & 0.026 & & {$[0.009$} & $0.050]$ & & \\
\hline$d_{\text {ULS }}$ & 0.007 & & {$[0.000$} & $0.015]$ & & \\
\hline $\mathrm{d}_{\mathrm{G}}$ & 0.003 & & {$[0.000$} & $0.008]$ & & \\
\hline$R^{2}$ & 0.114 & & {$[0.041$} & $0.226]$ & & \\
\hline Adjusted $R^{2}$ & 0.107 & & {$[0.033$} & $0.220]$ & & \\
\hline NFI & 0.989 & & & & & \\
\hline Chi-squared & 1.913 & & & & & \\
\hline
\end{tabular}

Significance and bias-corrected confidence intervals are based on a 5000 iterations bootstrapping procedure; $\beta$ : Original path values; SD: Standard Deviation; LO95/HI95: 95\% bias-corrected confidence intervals; $\mathrm{f}^{2}$ : Cohen's effect size; $\mathrm{Q}^{2}$ : cross-validated redundancies Stone-Geisser $\mathrm{Q}^{2}$ index; SRMR: Standardized Root Mean Square Residual; $\mathrm{d}_{\mathrm{ULS}}$ : Unweighted Least Squares discrepancy; $\mathrm{d}_{\mathrm{G}}$ : Geodesic discrepancy; $\mathrm{R}^{2}$ : coefficient of determination; NFI: Normal Fit Index; $* * 0.001$.

These results suggest that the CSV strategy had a positive and significant impact on the financial performance of hotels $\left(\beta=0.338^{* *}\right)$. Thus, $\mathrm{H} 1$ is accepted. Figure 2 shows the path coefficients and their bootstrapping significance levels.

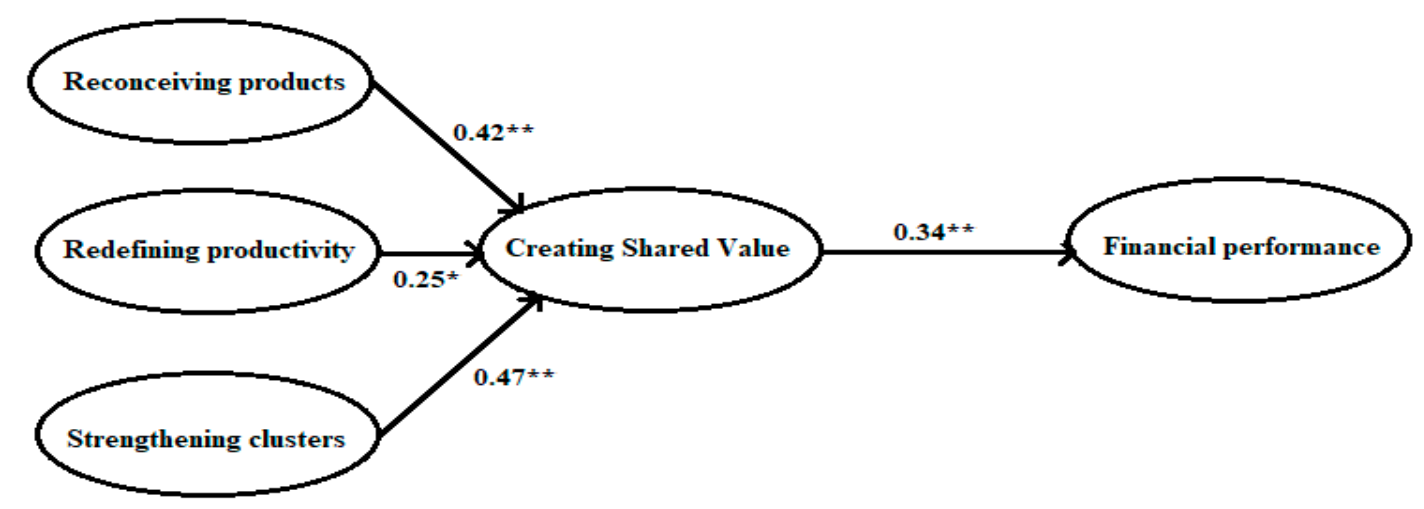

Figure 2. Path coefficients and bootstrapping significance levels for H1.

\subsection{Tests for Moderating Effects}

In order to test $\mathrm{H} 2$, the measurement invariance of composite constructs was determined by applying the MICOM procedure [38] to multigroup analyses for four dichotomized variables: Belonging to a group, market segment, star rating, and size. Compositional invariance for all the grouping criteria was demonstrated, and thus moderator analyses could be performed. As no equality of means was found in star ratings in step 3, a parametric test would not be appropriate to test the moderating effect of such variable. Tables 6 and 7 show the MICOM and moderating analyses results, respectively. 
Table 6. Measurement Invariance of Composites (MICOM) results.

\begin{tabular}{|c|c|c|c|c|c|c|c|c|c|c|c|c|}
\hline \multirow[t]{2}{*}{$\begin{array}{l}\text { Group } \\
\text { Criterion }\end{array}$} & \multirow[t]{2}{*}{ Construct } & \multicolumn{3}{|c|}{ Compositional Invariance } & \multicolumn{4}{|c|}{ Equal Means Test } & \multicolumn{4}{|c|}{ Equal Variances Test } \\
\hline & & Correlation & LO95 & $p$ & Diff & LO95 & HI95 & $p$ & Diff & LO95 & HI95 & $p$ \\
\hline Belonging & $\begin{array}{c}\text { Financial } \\
\text { P. }\end{array}$ & 1.00 & 1.00 & & -0.27 & -0.36 & 0.34 & 0.13 & 0.44 & -1.17 & 1.23 & 0.52 \\
\hline to a group & CSV & 0.97 & 0.93 & 0.25 & -1.11 & -0.37 & 0.36 & & -0.39 & -0.45 & 0.51 & 0.11 \\
\hline Star rating & $\begin{array}{c}\text { Financial } \\
\text { P. }\end{array}$ & 1.00 & 1.00 & & -0.55 & -0.36 & 0.36 & 0.00 & 0.35 & -1.19 & 1.26 & 0.59 \\
\hline \multirow{3}{*}{ Size } & CSV & 0.95 & 0.91 & 0.14 & -1.33 & -0.36 & 0.35 & & -0.47 & -0.45 & 0.51 & 0.06 \\
\hline & $\begin{array}{l}\text { Financial } \\
\text { P. }\end{array}$ & 1.00 & 1.00 & 0.22 & 0.24 & -0.34 & 0.34 & 0.18 & 0.87 & -1.20 & 1.23 & 0.19 \\
\hline & CSV & 1.00 & 0.95 & 0.64 & -0.19 & -0.34 & 0.35 & 0.29 & -0.41 & -0.46 & 0.48 & 0.09 \\
\hline Market & $\begin{array}{c}\text { Financial } \\
\text { P. }\end{array}$ & 1.00 & 1.00 & & -0.01 & -0.35 & 0.38 & 0.95 & -0.36 & -1.31 & 1.19 & 0.60 \\
\hline segment & CSV & 0.97 & 0.92 & 0.21 & -0.80 & -0.38 & 0.37 & & -0.21 & -0.55 & 0.44 & 0.40 \\
\hline
\end{tabular}

Significance $(p)$ and 95\% bias-corrected confidence intervals (LO95/HI95) are based on a 5000 iterations bootstrapping procedure. Diff: Difference between groups.

Table 7. Multigroup analyses.

\begin{tabular}{ccccccccc}
\hline & \multicolumn{3}{c}{ Permutation } & \multicolumn{2}{c}{ W-S Test } & \multicolumn{2}{c}{ Parametric } \\
\hline & Group 0 & Group 1 & Diff. & $p$-Value & t & $p$-Value & t & $p$-Value \\
\hline $\begin{array}{c}\text { Belonging to a } \\
\text { group }\end{array}$ & 0.188 & 0.585 & 0.397 & 0.008 & 2.307 & 0.024 & 1.983 & 0.05 \\
$\begin{array}{c}\text { Star rating } \\
\text { Size }\end{array}$ & 0.158 & 0.397 & 0.239 & 0.134 & 1.178 & 0.243 & & \\
$\quad \begin{array}{c}\text { Market } \\
\text { segment }\end{array}$ & 0.341 & 0.428 & 0.087 & 0.581 & 0.697 & 0.488 & 0.696 & 0.488 \\
\hline
\end{tabular}

W-S: Welch-Satterthwait tests. Diff: differences between groups.

None of the variables moderated the relationship between CSV and financial performance, except for the variable belonging to a group. Figure 3 shows this effect. Thus, only H2a is accepted.

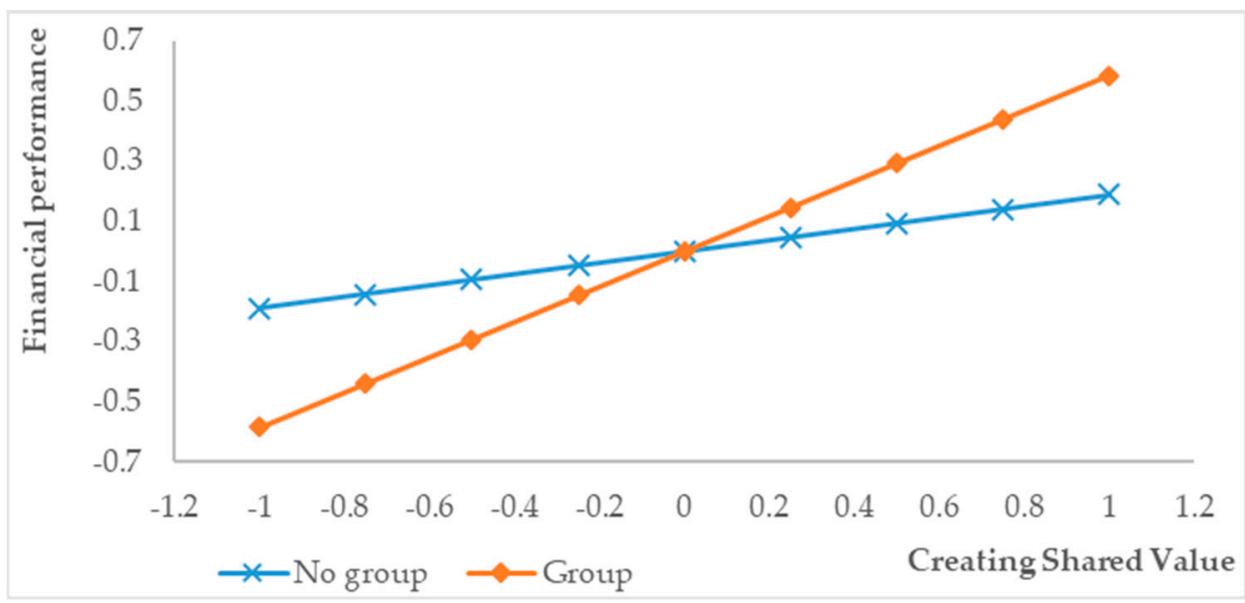

Figure 3. Moderator effect of belonging to a group.

\section{Conclusions and Implications}

Overall, this study contributes to empirical research on CSV and specifically to research on the effect of CSV on the financial performance of companies. The results show that the hotels that applied more CSV strategies achieved superior financial performance and that belonging to a group had a moderating effect that tended to strengthen the association between CSV and financial performance. In this setting, the effects of CSV were independent of hotel size, market segment, and star rating. 
The key contribution of this study is the empirical verification of the competitive advantages achieved by companies that apply CSV strategies. The results show that hotels that invest in socially responsible initiatives can generate a shared value between tourism companies and their stakeholders.

In addition, the establishment of a direct association between social outcomes and financial performance may help hotel managers recognize that the outcome of CSV strategies does not depend on the characteristics of their establishments alone because the positive effects of CSV strategies have been verified in all organizational environments of the hotel industry. Therefore, hotels can guarantee the competitiveness of their companies by becoming more actively engaged in CSV. As such, hotel managers can facilitate CSV activities in order to be closer to the demands and needs of relevant stakeholders, such as customers, suppliers, and citizens.

Furthermore, the results provide governments with evidence that responsible practices are capable of generating value for companies. Thus, governments could offer the hotel industry with incentives and propose new regulatory measures favoring socially responsible behavior. Currently, the social contribution of the tourism industry to mature and saturated destinations is undergoing deep political and social analysis. New formulas backed by information and communication technologies are being added to the ones used by traditional industries. For this reason, the results suggest that CSV can provide the hotel industry with new opportunities and competitive advantages by identifying and incorporating new social demands in the business model and by the objective measurement of its results.

The application of CSV strategies contributes to the sustainability of the hotel industry activity since the more committed to the society and the responsible practices the better economic results they get, as stated in this study. Thus, the main actors of the hotel industry find in CSV a powerful tool to face the challenges that arose from the demands of a greater contribution to sustainable development.

The present study should be evaluated in light of its limitations, which point to possible lines of future research. Firstly, some aspects of social benefits, such as satisfaction with the level of fulfilled needs, can only be appropriately addressed by stakeholders. Thus, future research could analyze the perceptions of external stakeholders concerning satisfied needs. Finally, researchers could use other samples and research designs that could provide results that differ from those reported in this study.

Author Contributions: This study has been designed and performed by all of the authors. A.M.G.R. and R.B.V. collected the data, M.Á.F.-G. and D.R.-P. developed the methodology and analyzed the data. The introduction, literature review and hypothesis were written by A.M.G.-R. and R.B.-V. All of the authors wrote the discussion and conclusions.

Funding: This research received no external funding.

Acknowledgments: The authors are grateful for the collaboration of AEHCOS for his help in the surveys.

Conflicts of Interest: The authors declare no conflict of interest. 


\title{
Appendix A
}

\section{SHARED VALUE QUESTIONNAIRE}

Name of establishment:

Star rating:

\author{
(Rate from $1=$ None to $5=$ Substantial)
}

a) Reconceiving products (Innovative products that meet previously unmet needs in the market) Offers sports facilities $1 \square 2 \square \quad 3 \square 4 \square \quad 5 \square$

Offers spa, sauna, or solarium $1 \square 2 \square 3 \square 4 \square 5 \square$

The establishment is located in or near nature $1 \square 2 \square 3 \square 4 \square 5 \square$

Offers medical and health services $1 \square 2 \square \quad 2 \square \quad 3 \square \quad 4 \square 5 \square$

Offers different types of pillows $1 \square 2 \square \quad 3 \square \quad 4 \square \quad 5 \square$

Offers healthier and more nutritive products $1 \square 2 \square 3 \square 4 \square 5 \square$

To what extent does it have cultural and commercial facilities? $1 \square 2 \square 3 \square 4 \square 5 \square$

Use of restored historic or artist ic buildings $1 \square 2 \square 3 \square 4 \square 5 \square$

Offers business center $1 \square 2 \square 3 \square 4 \square 5 \square$

Offers rooms with natural light $1 \square 2 \square 3 \square 4 \square 5 \square$

b) Redefining productivity (Evaluate the social impact of the value chain and redefine productivity accordingly) Use of air conditioning installations recently renewed $1 \square 2 \square 3 \square 4 \square 5$

Use of solar pane ls $1 \square \quad 2 \square \quad 3 \square \quad 4 \square 5 \square$

Use of auto matic on/off systems $1 \square 2 \square \quad 3 \square \quad 4 \square 5 \square$

Other technology for energy efficiency $1 \square 2 \square \quad 3 \square \quad 4 \square \quad 5 \square$

Workers with disabilities $1 \square 2 \square 3 \square 4 \square 5$

Absenteeism at Work $1 \square 2 \square 3 \square 4 \square 5 \square$

Workers with permanent contract or near-permanent contract $1 \square 2 \square 3 \square 4 \square \quad 5 \square$

Use of systems to reduce water consumption $1 \square 2 \square \quad 3 \square 4 \square \quad 5 \square$

Use of a recycling system $1 \square 2 \square 3 \square \quad 4 \square 5 \square$

Implementation of other environmental improvement techniques $1 \square \quad 2 \square \quad 3 \square \quad 4 \square \quad 5 \square$

Landscape areas $1 \square 2 \square 3 \square 4 \square 5 \square$

Technologies shared with suppliers $1 \square 2 \square \quad 3 \square \quad 4 \square \quad 5 \square$

Aid provided to suppliers $1 \square 2 \square \quad 3 \square 4 \square 5 \square$

Use of supplier credit $1 \square 2 \square 3 \square 4 \square 5 \square$

Purchasing from local suppliers $1 \square 2 \square 3 \square 4 \square 5 \square$

Training programs for workers $1 \square 2 \square 3 \square 4 \square 5 \square$

Health programs for workers $1 \square 2 \square 3 \square 4 \square 5 \square$

Work safety programs for worker $1 \square 2 \square \quad 3 \square \quad 4 \square 5 \square$

c) Streng thening clusters (Cooperation between companies and organizations)

Collaboration with business associations $1 \square 2 \square \quad 3 \square 4 \square 5 \square$

Quality certif icates granted to the establishment $1 \square 2 \square \quad 3 \square \quad 4 \square 5 \square$

Use of services provided by universities $1 \square 2 \square 3 \square 4 \square 5 \square$

Use of services provided by vocational training schools $1 \square 2 \square 3 \square 4 \square 5 \square$

Send de completed questionnaire to AEHCOS by FAX to the number 952374026 o by email: info@aehcos.es 


\title{
Appendix B
}

\section{EXPERT EVALUATION OF THE SHARED VALUE QUESTIONNAIRE $\underbrace{\text { ma }}$ Rehcos}

\author{
Full name: \\ Organism: \\ Dpt./Centre: \\ Address: \\ Phone number: \\ Professional category:
}

Inform about:

1) The adequacy of the questions in the questionnaire to the purpose of the investigation

2) The structure and balanced arrangement of its parts

3) If any part or set of essential questions is missing

4) If some questions are repetitive

\section{Construct}

Code

Reconceiving

products

PDT1, РDT2, РDT3, РDT4

Redefining
productivity $\quad$ PVC1, PVC2, PVC3, PVC4, PVC5

Strengthening

clusters

1
CLU1, CLU2, CLU3, CLU4

Evaluation

1)

2)

3)

4)

1)

2)

4)

1)

2)

3)

4)

Send evaluation to AEHCOS by FAX to the number 952374026 o by email: info@aehcos.es

\section{References}

1. $\quad$ Porter, M.; Kramer, M. Creating Shared Value. Harv. Bus. Rev. 2011, 89, 62-77.

2. Kim, J.D.; An, H.-T.; Myung, J.K.; Bae, S.M. Assesing CSV as a Successuful Strategic CSR. Korea Buss Rev. 2016, 20, 291-318. [CrossRef]

3. Dembek, K.; Singh, P.; Bhakoo, V. Literature Review of Shared Value: A Theoretical Concept or a Management Buzzword? J. Bus. Eth. 2016, 137, 231-267. [CrossRef]

4. Jones, P.; Hillier, D.; Comfort, D. The Sustainable Development Goals and the Tourism and Hospitality Industry. Athens J. Tour. 2017, 4, 7-17. [CrossRef] 
5. Lichtenthaler, U. Shared Value Innovation: Linking Competitiveness and societal goals in the context of digital transformation. Int. J. Innov. Technol. Manag. 2017, 14, 1-14. [CrossRef]

6. Pfitzer, M.W.; Bockstette, V.; Stamp, M. Innovating for shared value. Companies that deliver both social benefits and business value rely on five mutually reinforcing elements. Harv. Bus. Rev. 2013, 91, 100-107.

7. Alberti, F.G.; Belfanti, F. Creating Shared Value and clusters. The case of an Italian cluster initiative in food waste prevention. Compet. Rev. 2019, 29, 39-60.

8. Camilleri, M.A. Creating Shared Value through Strategic CSR in Tourism. Ph. D. Thesis, University of Edinburgh, Edinburgh, UK, 2012.

9. Drozdz, S.; Dufwa, M.; Meconnen, R.; Solberg, K. An assessment of customer shared value in the restaurant industry-A survey from Sweden. Theor. Appl. Econ. 2015, 22, 85-98.

10. Hsiao, T.Y.; Chuang, C.M. Creating Shared Value through Implementing Green Practices for Star Hotels. Asia Pac. J. Tour. Res. 2016, 21, 678-696. [CrossRef]

11. Grezes, V.; Perruchoud, A. From Business Model Design to the Identification of Potential Business Innovation through the Creation of Shared Value: The Case of Tourism in a Region of Switzerland; IIMC International Information Management Corporation: Belfast, UK, 2014.

12. Lim, J.E. The Moderating effects of Organizational Identity on the Creating Shared Value of Hotel and Organizational Loyalty. J. Korea Contents Assoc. 2016, 16, 630-637. [CrossRef]

13. Porter, M.E.; Kramer, M.R. Strategy and society: The link between competitive advantage and corporate social responsibility. Harv. Bus. Rev. 2006, 84, 78-92. [PubMed]

14. Wheeler, D.; Colbert, B.; Freeman, R.E. Focusing on Value: Reconciling Corporate Social Responsibility, Sustainability and a Stakeholder Approach in a Network World. J. Gen. Manag. 2003, 28, 1-28. [CrossRef]

15. Jonikas, D. Conceptual framework of value creation through CSR in separate member of value creation chain. Bull. Geogr. Socio-Econ. Ser. 2013, 21, 69-78. [CrossRef]

16. Maltz, E.; Schein, S. Cultivating shared value initiatives: A three Cs approach. J. Corp. Citizsh. 2012, 47, 55-74. [CrossRef]

17. Li, W.; Sadick, M.A.; Musah, A.-A.I.; Mustapha, S. The Moderating Effect of Social Innovation in Perspectives of Shared Value Creation in the Educational Sector of Ghana. Sustainability 2018, 10, 4216. [CrossRef]

18. Font, X.; Guix, M.; Prieto-Bonilla, M.J. Corporate social responsibility in cruising: Using materiality analysis to create shared value. Tour. Manag. 2016, 53, 175-186. [CrossRef]

19. Sánchez-Hernandez, M.I.; Bañegil Palacios, T.; Sanguino-Galván, R. Competitive Success in Responsible Regional Ecosystems: An Empirical Approach in Spain Focused on the Firms' Relationship with Stakeholders. Sustainability 2017, 9, 449. [CrossRef]

20. Rezaee, Z. Supply chain management and business sustainability synergy: A theoretical and integrated perspective. Sustainability 2018, 10, 275. [CrossRef]

21. Crane, A.; Palazzo, G.; Spence, L.; Matten, D. Contesting the value of "creating shared value". Calif. Manag. Rev. 2014, 56, 130-149. [CrossRef]

22. Corner, P.D.; Pavlovich, K. Shared value through inner knowledge creation. J. Bus. Ethics 2016, 135, 543-555. [CrossRef]

23. Leavy, B. Getting back to what matter-Creating long-term economic and social value. Strategy Leadersh. 2012, 40, 12-20. [CrossRef]

24. Farache, F.; Perks, K. CSR advertisements: A legitymacy tool? Corp. Commun. Int. J. 2010, 15, $235-248$. [CrossRef]

25. Porter, M.; Hills, G.; Pfitzer, M.; Patscheke, S.; Hawkins, E.; Measuring Shared Value. How to Unlock Value by Linking Social. 2012. Available online: https://www.fsg.org/publications/measuring-shared-value\# download-area (accessed on 15 December 2018).

26. Vidal, I. El principio de valor compartido. Boletín del Centro de Investigación de Economía y Sociedad (CIES); University of Barcelona: Barcelona, Spain, 2011; Volume 92.

27. Porter, M.E. Competition in Global Industries; Harvard Business School Press: Boston, MA, USA, 1986.

28. Dekker, R.; Bloemhof, J.; Mallidis, I. Operations Research for green logistics-An overview of aspects, issues, contributions and challenges. Eur. J. Oper. Res. 2012, 219, 671-679. [CrossRef]

29. Bertini, M.; Gourville, J.T. Pricing to create shared value. Harv. Bus. Rev. 2012, 90, 96-104.

30. Sojamo, S.; Larson, E.A. Investigating food and agribusiness corporations as global water security, management and governance agents: The case of Nestlé, Bunge and Cargill. Water Altern. 2012, 5, 619-635. 
31. Kruschwitz, N. Creating shared value at Nestlé. MIT Sloan Manag. Rev. 2013, 55, 1-3.

32. Mahindra, A.G. Business and society in the twenty-first century-beyond CSR. NHRD Netw. J. 2012, 5, 36-40. [CrossRef]

33. Camilleri, M.A. Responsible tourism that creates shared value among stakeholders. Tour. Plan. Dev. 2016, 13, 219-235. [CrossRef]

34. Fernández, M.A.; Becerra, R. An Analysis of Spanish Hotel Efficiency. Cornell Hosp. Q. 2015, 56, $248-257$. [CrossRef]

35. Pereira-Moliner, J.; Font, X.; Molina-Azorin, J.F.; Tarí, J.J.; Lopez-Gamero, M.D.; Pertusa-Ortega, E.M. The Holy Grail Environmental management, competitive advantage and business performance in the Spanish hotel industry. Int. J. Contemp. Hosp. Manag. 2015, 27, 714-738. [CrossRef]

36. Sanjeev, G.M. Measuring efficiency of the hotel and restaurant sector: The case of India. Int. J. Contemp. Hosp. Manag. 2007, 19, 378-387. [CrossRef]

37. Lado-Sestayo, R.; Fernández, E.; Seijas, M.N. Impacto de la crisis económica en la estructura económico-financiera de Paradores S.A. RICIT Revista Turismo, Desarrollo y Buen Vivir 2017, 11, 78-98.

38. Claver, E.; Molina, J.F.; Pereira, J. The impact of strategic behaviors on hotel performance. Int. J. Contemp. Hosp. Manag. 2007, 19, 6-20. [CrossRef]

39. INE. Hotel Establishments 2018. Instituto Nacional de Estadística. Available online: http:/ / www.ine.es / jaxiT3/Tabla.htm?t=2011\&L=0 (accessed on 10 December 2018).

40. Cohen, J. A Power Primer. Psychol. Bulletin. 1992, 112, 155-159. [CrossRef]

41. Diputación Provincial de Málaga. Turismo. 2018. Available online: http://www.malaga.es/es/turismo/ 3313/com1_md3_cd-35999/ (accessed on 10 December 2018).

42. Cataldo, R.; Grassia, M.R.; Lauro, N.C.; Marino, M. Developments in Higher-Order PLS-PM for the building of a system of Composite Indicators. Qual. Quant. 2017, 51, 657-674. [CrossRef]

43. Hair, J.F.; Hult, G.T.M.; Ringle, C.M.; Sarstedt, M. A Primer on Partial Least Squares Structural Equation Modeling (PLS-SEM), 2nd ed.; Sage: Thousand Oaks, CA, USA, 2017.

44. Becker, J.M.; Klein, K.; Wetzels, M. Hierarchical Latent Variable Models in PLS-SEM: Guidelines for Using Reflective-Formative Type Models. Long Range Plan. 2012, 45, 359-394. [CrossRef]

45. Henseler, J.; Ringle, C.M.; Sarstedt, M. Testing Measurement Invariance of Composites Using Partial Least Squares. Int. Mark. Rev. 2016, 33, 405-431. [CrossRef]

46. Chin, W.W.; Dibbern, J. A Permutation Based Procedure for Multi-Group PLS Analysis: Results of Tests of Differences on Simulated Data and a Cross Cultural Analysis of the Sourcing of Information System Services between Germany and the USA. In Handbook of Partial Least Squares: Concepts, Methods and Applications; Esposito Vinzi, V., Chin, W.W., Henseler, J., Wang, H., Eds.; Springer: Berlin, Germany, 2010.

47. Henseler, J.; Ringle, C.M.; Sinkovics, R.R. The use of partial least squares path modeling in international marketing. Adv. Int. Mark. 2009, 20, 277-320.

48. Sarstedt, M.; Henseler, J.; Ringle, C. Multigroup Analysis in Partial Least Squares (PLS) Path Modeling: Alternative Methods and Empirical Results. Adv. Int. Mark. 2011, 22, 195-218.

49. Reinartz, W.; Haenlein, M.; Henseler, J. An empirical comparison of the efficacy of covariance-based and variance-based SEM. Int. J. Res. Mark. 2009, 26, 332-344. [CrossRef]

50. Roldán, J.L.; Sánchez-Franco, M.J. Variance-based structural equation modeling: Guidelines for using partial least squares in information systems research. In Research Methodologies in Engineering of Software Systems and Information Systems: Philosophies, Methods and Innovations; Mora, M., Gelman, O., Steenkamp, A., Raisinghani, M., Eds.; Information Science Reference; IGI Global: Hershey, PA, USA, 2012.

51. Barroso, C.; Cepeda, G.; Roldán, J.L. Applying maximum likelihood and PLS on different sample sizes: Studies on SERVQUAL model and employee behaviour model. In Handbook of Partial Least Squares: Concepts, Methods and Applications; Esposito Vinzi, V., Chin, W.W., Henseler, J., Wang, H., Eds.; Springer: Berlin, Germany, 2010.

52. Castro, I.; Roldán, J.L. A mediation model between dimensions of social capital. Int. Bus. Rev. 2013, 22, 1034-1050. [CrossRef]

53. Wold, H. Systems analysis by partial least squares. In Measuring the Unmeasurable; Nijkamp, P., Leitner, H., Wrigley, N., Eds.; Martinus Nijhoff Publishers: Dordrecht, The Netherlands, 1985. 
54. Chin, W.W. How to write up and report PLS analyses. In Handbook of Partial Least Squares: Concepts, Methods and Applications; Esposito Vinzi, V., Chin, W.W., Henseler, J., Wang, H., Eds.; Springer: Berlin, Germany, 2010.

55. Segarra-Moliner, J.R.; Moliner-Tena, M.A. Customer equity and CLV in Spanish telecommunication services. J. Bus. Res. 2016, 69, 4694-4705. [CrossRef]

56. Ringle, C.M.; Wende, S.; Becker, J.M. Smart PLS 3.2.6. Boenningstedt: SmartPLS GmbH [computer software]. 2018. Available online: http:/ / www.smartpls.com (accessed on 22 October 2018).

57. Nwachukwv, S.; Vitell, S.; Gilbert, F.; Barnes, J. Ethics and social responsibility in marketing: An examination of the ethics evaluation of advertising strategies. J. Bus. Res. 1997, 39, 107-118. [CrossRef]

58. Podsakoff, P.M.; MacKenzie, S.B.; Lee, J.Y.; Podsakoff, N.P. Common method biases in behavioral research: A critical review of the literature and recommended remedies. J. Appl. Psychol. 2003, 88, 879-903. [CrossRef]

59. Lindell, M.K.; Whitney, D.J. Accounting for common method variance in cross-sectional research designs. J. Appl. Psychol. 2001, 86, 114-121. [CrossRef] [PubMed]

60. Henseler, J. Adanco 2.0.1.User Manual; Composite modelling, GmbH \& Co.: Kleve, Germany, 2017.

61. Hair, J.F.; Sarstedt, M.; Ringle, C.M.; Mena, J.A. An assessment of the use of partial least squares structural equation modeling in marketing research. J. Acad. Mark. Sci. 2012, 40, 414-433. [CrossRef]

62. Diamantopoulos, A. The error term in formative measurement models: Interpretation and modeling implications. J. Model. Manag. 2006, 1, 7-17. [CrossRef]

63. Tenenhaus, M.; Esposito, V.; Chatelin, Y.; Lauro, C. PLS path modeling. Comput. Stat. Data Anal. 2005, 48, 159-205. [CrossRef]

64. Dijkstra, T.K.; Henseler, J. Consistent partial least squares path modeling. MIS Q. 2015, 39, $297-316$. [CrossRef]

65. Carmines, E.G.; Zeller, R.A. Reliability and Validity Assessment; Sage Publications: Thousand Oaks, CA, USA, 1979.

66. Barclay, D.; Higgins, C.; Thompson, R. The Partial Least Squares (PLS) approach to causal modeling, personal computer and use as an illustration (Special Issue on Research Methodology). J. Technol. Stud. 1995, 2, 285-309.

67. Henseler, J.; Ringle, C.M.; Sarstedt, M. A new criterion for assessing discriminant validity in variance-based structural equation modeling. J. Acad. Mark. Sci. 2015, 43, 115-135. [CrossRef]

68. Hair, J.F.; Ringle, C.; Sarstedt, M. PLS-SEM: Indeed a silver bullet. J. Mark. Theory Pract. 2011, 19, $139-152$. [CrossRef]

69. Henseler, J.; Dijkstra, T.K.; Sarstedt, M.; Ringle, C.M.; Diamantopoulos, A.; Straub, D.W. Common beliefs and reality about partial least squares: Comments on Rönkkö \& Evermann (2013). Organ. Res. Methods 2014, 17, 182-209.

70. Hu, L.T.; Bentler, P.M. Fit indices in covariance structure modeling: Sensitivity to underparameterized model misspecification. Psychol. Methods 1998, 3, 424-453. [CrossRef]

71. Dijkstra, T.K.; Henseler, J. Consistent and asymptotically normal PLS estimators for linear structural equations. Comput. Stat. Data Anal. 2015, 81, 10-23. [CrossRef]

(C) 2019 by the authors. Licensee MDPI, Basel, Switzerland. This article is an open access article distributed under the terms and conditions of the Creative Commons Attribution (CC BY) license (http:/ / creativecommons.org/licenses/by/4.0/). 